\title{
Global Trends and Transitions in Think Tanks, Politics, and Policy Advice in the Age of Policy Dilemmas and Disruptions
}

\author{
James G. McGann
}

\begin{abstract}
Throughout the twentieth century think tanks stood at the forefront of academic work examining global developments, collecting and analyzing information to provide important insights that form and guide policy- and decision-making. However, the general trend of globalization, as well as digitalization, informatization, and changes in how information is obtained and consumed, has placed think tanks at a disadvantage. These trends are undermining the authoritative position of think tanks and requiring them to find new and innovative ways to present information so that they remain relevant in today's world. Think tanks are uniquely equipped to provide policy suggestions that governments and business need to make correct and effective decisions. However, crises like COVID-19 also present new obstacles for think tanks in terms of how to communicate information and promote engagement to ensure that they remain relevant and valuable. Over the last decade, forces have redefined the strategy and structure of many think tanks. This momentum is primarily driven by changes in politics, how think tanks are funded, and advances in technology and communications. During this period, there have been five key trends originating in the fourth industrial revolution that will transform jobs and lives over the next 10 years.
\end{abstract}

Keywords Think tanks stood at the forefront of academic work examining global developments $\cdot$ Think tanks at a disadvantage $\cdot$ Undermining the authoritative position of think tanks $\cdot$ Think tanks are uniquely equipped to provide policy suggestions - Over the last decade, forces have redefined the strategy and structure of many think tanks - Five key trends originating in the fourth industrial revolution

J. G. McGann ( $₫)$

Think Tanks and Civil Societies Program, Wharton School and School of Arts and Sciences, Philadelphia, PA, USA

Fels Institute of Government, University of Pennsylvania, Philadelphia, PA, USA

(C) The Author(s) 2021

H. Wang and A. Michie (eds.), Consensus or Conflict?, China and Globalization, https://doi.org/10.1007/978-981-16-5391-9_17 


\section{Revitalizing Think Tanks to Meet Unprecedented Global Threats}

Recent years have seen changes in the international order and economics that are reshaping the world. Trends away from multinationalism in developed countries, like the United States and Europe, the rise of China, and unavoidable changes in the status and function of international organizations, ranging from NATO to the $\mathrm{UN}$ and WHO, are forcing governments, organizations, and societies to rethink their approach to global issues.

Throughout the twentieth century, especially after World War II, think tanks have stood at the forefront in examining global developments, collecting and analyzing information to provide important insights that form and guide policy- and decisionmaking. However, the general trend of globalization, as well as digitalization, informatization, and changes in how information is obtained and consumed, has placed think tanks at a disadvantage. These trends are undermining think tanks' authoritative position and requiring them to find new and innovative ways to present information so that they remain relevant in today's world.

Global crises, like COVID-19 in particular, have been both a blessing and a curse for think tanks. The challenges that these crises present require the careful and insightful analysis that think tanks are uniquely equipped to provide and that governments and businesses need to make correct and effective decisions. However, these crises also present new obstacles for think tanks in terms of how to communicate this information and promote engagement to ensure that they remain relevant and valuable.

\section{What Is a Think Tank?}

First of all, I would like to revisit what think tanks are and what functions they serve. Think tanks are public policy research analysis and engagement organizations that generate policy-oriented research, analysis, and advice on domestic and international issues, thereby enabling policy-makers and the public to make informed decisions about public policy. Think tanks may be affiliated or independent institutions that are structured as permanent bodies, not ad hoc commissions. These institutions often act as a bridge between the academic and policy-making communities and between states and civil society, serving in the public interest as an independent voice that translates applied and basic research into a language that is understandable, reliable, and accessible for policy-makers and the public.

Over the last 90 years, several distinct organizational forms of think tanks have emerged. These differentiate themselves in terms of their operating styles, patterns of recruitment and aspirations, to academic standards of objectivity and completeness in research. It should be noted that alternate typologies of think tanks have been offered by other analysts. In the global context, most think tanks tend to fall into the following broad categories: 
1. Autonomous and independent, enjoying significant independence from any one interest group or donor, and autonomous in its operation and funding from the government.

2. Quasi-independent, autonomous from government, but controlled by an interest group, donor, or contracting agency that provides most of the funding and has significant influence over operations of the think tank

3. Government-affiliated, or a part of the formal structure of government.

4. Quasi-governmental, which means that it is funded exclusively by government grants and contracts but not a part of the formal structure of government.

5. University-affiliated, which are mostly policy research centers at universities.

6. Political party-affiliated, which are formally affiliated with a political party.

7. Corporate, which are for-profit public policy research organizations, affiliated with a corporation or merely operating on a for-profit basis.

The end of the Post-World War II consensus and challenge to the welfare state contributed to the growth of think tanks on the left and the right of the political spectrum. There are currently 2,397 think tanks in North America (Mexico, Canada, and the United States) of which 2,203 are in the United States, while Europe contains 2,932 think tanks. These two regions contain over $47 \%$ of the world's think tanks. The number of think tanks in the United States has more than doubled since 1980 and most of these that have come into existence since the 1970s are specialized for a particular regional or functional area.

Asia, Latin America, Africa, the Middle East, and North Africa continue to see an expansion in the number and type of think tanks established, experiencing dramatic growth since the mid-2000s. University and government-affiliated/funded think tanks remain the dominant model and are dependent on government funding along with gifts, grants, and contracts from international public and private donors.

Generally, the growth of think tanks in the twentieth and into the twentyfirst centuries can be attributed to these factors: industrial and technological revolution; the end of government monopolies on information and a crisis of confidence in the government itself, and elected officials, as well as the increasing complexity in and technical nature of policy problems. However, in recent years, the number of think tanks worldwide has begun to see a decline. This is mainly due to a failure to understand and respond to non-traditional competition and adopt new technologies and marketing strategies. There has also been a decrease in funding by both public and private donors, who have become more focused on short-term funding projects as opposed to research and institutions. Finally, increased competition from advocacy organizations, for-profit consulting firms, and 24/7 electronic media has also affected the flow of information and its consumption. All these trends have challenged the traditional position and model of the think tank.

As think tanks, we must face the reality that there will be no new normal, only a series of extraordinary events that will create a world where disruptions and the abnormal will be the norm. Big ships turn slowly and think quickly in storms. So only the innovative and agile will survive this most recent COVID storm. The imperative is now more urgent since the winds of change have intensified and accelerated the 
trends. Only those think thanks that are smarter, better, faster, tech-savvy, and agile will be able to weather the storm.

\section{The Function of Think Tanks in Global Crises like COVID-19}

From April through July 2020, the Think Tank and Civil Societies Program (TTCSP) of the Lauder Institute at the University of Pennsylvania hosted a series of virtual "Global Think Tank Town Halls to Save Lives and Livelihoods." The aim was to respond rapidly and proactively as a global think tank community to the novel corona virus (COVID-19). The pandemic has proven to be an unprecedented threat to the health, economic well-being, and general livelihood of people all over the globe. TTCSP has recognized the value that the think tank community can provide to policymakers, and the public, as they work toward mitigating the consequences of COVID19. The Global Think Tank Town Halls served as space for the community to convene and mobilize. 1,226 think tank executives, scholars, and policy-makers from over 540 institutions in over 87 countries met over the course of the three Town Halls to produce actionable responses and solutions to the devastating consequences of the virus.

The first Global Think Tank Town Hall made note that think tanks must become stronger, smarter, and faster in response to COVID-19 and create effective policy recommendations to support vulnerable and impacted sectors around the world.

The second Global Think Tank Town Hall saw the creation of five Working Groups that focused on (1) the public health crisis; (2) preparing national and international strategies for economic recovery and revitalization; (3) identifying innovative and inclusive public and private intervention strategies to help vulnerable groups; (4) fostering international cooperation by creating rapid, responsive, and resilient systems to respond to future crises; and (5) new operating models for think tanks-research, communications, and funding.

The third and final Global Think Tank Town Hall saw each Working Group present their recommendations and key proposals. Each Working Group conducted their analyses and formulated strategic and actionable recommendations within 45 days, reflecting the ability of the think tank community to convene from all corners of the world and produce tangible results in a short span of time. Below are the key recommendations from each Working Group on the five key issues analyzed.

\subsection{Public Health Crisis}

Working Group 1 analyzed the impact of increased globalization, which has not only integrated nations and economies but has also led to the internationalization of infectious diseases. One focal point was knowledge and information sharing, focusing on the importance of collecting consistent, reliable, and disaggregated 
data; investing in collaboration, innovation, and distribution; and streamlining the regulatory environment and reforming legal regimes to allow innovations.

The Working Group additionally gave recommendations for best practices in managing the public health crisis, which included sharing experiences and simulation models to inform policy. They also discussed the need for research-based solutions and policies, which think tanks can play a role in. The think tank community has the potential to necessitate the augmentation of state capacity, during a pandemic and otherwise. The importance of accelerating progress toward universal health coverage was emphasized, as was the need for the equitable distribution of vaccines, medicines, and capabilities.

\subsection{Preparing National and International Strategies}

Working Group 2 focused on targeting sustainable and broader-based economic recovery, focusing on shaping free-market policies that empower a circular economy and science-based target initiative tools. The Working Group laid out a handful of basic principles that governments should adhere to in order to rebuild national and global economies. These included prioritizing green recovery, international cooperation, democracy and inclusive free markets, market-driven responses to infectious diseases, and dynamic and flexible policies.

The Working Group also noted the importance of prioritizing digitization moving forward. Think tanks can be pivotal in encouraging governments to promote digital transformation and inclusion, as well as support the international community in accelerating talks to reduce the risk of privacy invasion and cyberthreats with greater technological regulation. Finally, they highlighted the importance of shaping the informal economy into an agent of recovery by focusing on three key pillars: building updated databases, making formal employment the easiest and most desired solution, and adopting a comprehensive reform approach to the informal economy. Think tanks can play a key role in shaping policy in this direction.

\subsection{Innovative and Inclusive Public and Private Strategies to Help Vulnerable Groups}

Working Group 3 focused on five particular vulnerable groups: children and youth, the elderly, women in vulnerable conditions, migrants, and racial and ethnic minorities. Regarding children and youth, key recommendations include monitoring the functioning of institutions responsible for the protection of children, ensuring working parents have sufficient time to care for children, and equitable access to safe medical services to all families and youth. For the elderly, it must be ensured that WHO and CDC guidelines for long-term care facilities are effectively implemented, as well as access to phone and video call technology for those in long-term care 
facilities that require sufficient funding. Regarding women in vulnerable conditions, think tanks should advocate for the development of economic empowerment tools so women are better equipped to be financially independent; furthermore, think tanks can also help shape policy that creates better awareness regarding what constitutes violence against women.

For migrants, it is imperative that states implement protective measures to ensure migrants' rights to personal security and access to basic rights such as food and healthcare; furthermore, the Working Group recommends eliminating custodial detention methods. Finally, for racial and ethnic minorities, recommended policies include localizing and diversifying service and supply chains to support minority-owned businesses; assuring basic items of consumption in minority neighborhoods; improved local government to support housing and employment stability; and prioritizing public health programming with stronger consideration of the social determinants of health.

\subsection{Fostering International Cooperation: Creating Rapid, Responsive, and Resilient Systems to Respond to Future Crisis}

Working Group 4 looked at how to better shape resilient policies and systems to respond not only to COVID-19 but also future crises by focusing on strategies that can be adopted at the local, regional, and global levels. On the local level, technology should be used to effectively control and distribute resources; direct assistance via managing commercial and supply chains, financial relief, and tax exemptions is vital; and unified programs to administer tests throughout the pandemic should be developed.

Regionally, efforts should focus on strengthening regional multilateral organizations and coordinating initiatives and consensual operational protocols between countries. Globally, the Working Group proposes that the international community should prioritize strengthening global multilateral organizations; creating new multilateral cooperation and crisis committees; sharing information systems and technologies for pandemic detection and control; internationally coordinating fiscal and monetary policies; and, finally, creating new sustainability and debt financing framework for low-income countries.

\subsection{Being Fit for an Uncertain Future: New Operating Models for Think Tanks—Research, Communications, and Funding}

Working Group 5 focused on four key areas in which think tanks can strengthen their operating models moving forward: communications, events, fundraising, and research priorities. Regarding communication, think tanks should work in niche intersections of COVID-19 and specific issues in which think tanks have the expertise, 
focus on highly visible communications and stakeholder outreach initiatives, and invest in new and diverse online formats of communications. Think tanks should also reimagine events in the digital sphere, recognizing the potential for widening one's audience base while reducing the environmental impact of events.

Moving forward with fundraising, think tanks should engage with the private sector as partners in research projects, rather than solely as donors, and think tanks should build partnerships with other think tanks. Think tanks should also redirect and widen research priorities to break thematic silos culture and find new policy intersections, as well as develop thematic partnerships with other think tanks focused on long-term research projects.

A global crisis like COVID-19 highlights both the strengths and weaknesses of think tanks. Their ability to analyze crises and provide practical, objective policy direction for governments and organizations can help mitigate their negative impact on global economies and welfare. However, maintaining their professional and authoritative position in the face of a flood of information from social media and other sources is a serious challenge. That digital information tsunami will decide where think tanks go from here on out and how they allocate funding and support.

\section{The Future of Think Tanks and Policy Advice}

Over the past 10 years, I've been examining the forces that have transformed the policy environment in which think tanks operated and have forced them to redefine their strategy and structure. These forces are primarily driven by changes in politics, how think tanks are funded, and advances in technology and communication.

Over the last decade, there are four key trends that flow from the fourth industrial revolution that will transform all our jobs and lives over the next 10 years. It is these forces that are also driving the digital and political disruptions that are sweeping across the globe. They are:

- The dramatic increase in the rate of technological change.

- The disruptive and transformative power of social media, social networks, artificial intelligence, and big data.

- The increased velocity of information and policy flows.

- Information interdependence.

Digital and social networks are constantly being ended by new strategies and technologies which in turn increase the volume and velocity of information flow around the world. These new realities are making it possible to manage and manipulate massive amounts of data, which is disrupting business, politics, and public policy. Henry Kissinger, whom people in China know well and followed closely, famously said that "being a policymaker is like being at the end of a fire hose," which for those of you who are not familiar with the term is a high pressure and high volume hose that is used to fight fires. Policy-makers and the public are faced with a flood of issues, ideas, and actors, which have served to intensify competition, conflict, and 
to certain extent cooperation. This never-ending flood of competing ideas and information makes it difficult to process all the different ideas, options, and alternatives. How do we determine which product or policy is the best one? It is no surprise that in this environment, traditional approaches, in terms of ideas and information, are overlooked for the outrages and the outlanders. These forces have created a crowded and competitive global marketplace of ideas and policy advice. This poses very new and very challenging strategic and operational challenges for think tanks.

In the last 4 years, the trends outlined above have been compounded by two new forces that have intensified and accelerated the winds of change, and are likely to transform think tanks, policy advice, and public policy in ways that we previously could not imagine. One is the effort to discredit and undermine experts, policy advice, and think tanks. The second is the Covid-19 pandemic. These two additional trends have accelerated and compounded the transformation that is taking place and will force all think tanks to respond.

Furthermore, the dawn of the fourth industrial revolution is upon us, and will require think tanks to manage change, access, policy issues, and trends, and make recommendations more quickly than ever before. The pandemic has intensified those operation and think tanks of all types and size have never felt so much pressure to rethink how they operate to fit the changing environment. The Covid-19 pandemic and increased velocity of information and policy flows will continue to accelerate factors like digitalization, globalization, automatization, and analytics. What this means is that think tanks must become smarter, better, faster, more digital, more adaptive, and more agile if they have any hope of surviving.

It is precisely during these turbulent times when experts and their advice are being undermined. More importantly, the significant policy and technology disruptions calling into question the value and efficacy of policy advice has led to my conclusion. It is critical that we pause and reflect on the future of think tanks and policy advice.

\section{The Vital Need for a New Breed of Think Tanks}

Think tanks are crucial to conducting research, engaging scholars, and building partnerships. The rationale means dialogues, partnerships, and cooperation, embraced by think tanks, become essential in the face of many complex global challenges.

This is why think tanks in China, in the US, and around the world matter and matter more than ever before, and that is why we must work to make sure that think tanks are fit for an uncertain future.

Think tanks must face the reality that there will be no new normal, only a series of extraordinary events that will create a world where disruptions and the abnormal will be the norm. Only those think tanks that are smarter, better, faster, tech-savvy, and agile will be able to weather the storm. The mission of the think tanks and civil societies program at the Lauder Institute of the University of Pennsylvania is to help think tanks prepare to survive the storm so they can continue their service in the post-COVID era. 
The impact of technology; big data and artificial intelligence; competition from advocacy groups and public relations firms; increased polarization of politics; major changes in how think tanks are funded; and the impact of the COVID-19 pandemic on think tank operations are all major issues that affect think tanks around the world. Think tanks must be smarter, better, faster and more agile, innovative, and tech-savvy if they are to survive. I would like to now turn to a few issues that Chinese think tanks, in particular, face in addition to these more universal, global issues.

\section{Think Tanks the New Great Wall in China and Why Modernization and Reform is a National Imperative}

There are now over 11, 175 think tanks in our database and we have also collected in a very systematic way and identified 1415 think tanks in China. This reflects a dramatic increase in the number of think tanks in China and constitutes the most significant number of think tanks among the think tank leaders or leading countries in Asia: India, Korea, Australia, and Vietnam. Even more impressive is that over 600 of these think tanks have been established since 2000. However, there are a number of unique issues facing Chinese think tanks and hinder their integration into the global environment.

First, there are many blanks and gaps in the information that we have on Chinese think tanks, specifically on staffing, size, budget, and even basic information about their research programs. This is a huge information gap. The missing information highlights the lack of transparency surrounding the nature and operation of think tanks in China. Thirdly, the number of think tanks or the largest number of think tanks is still in Beijing which outnumbers the rest of think tanks proportionally in every other city in China. There are, as I said, 500 think tanks in Beijing, which makes about one-third of the total think tanks in China. This makes sense because Beijing is the political center, but more cities need to create think tanks to help with their regional or provincial issues.

There are a number of areas for improvement. First, the vast majority of think tanks in China do not have functional websites. In many respects, they are blackholes that have little or no information on them. For those that do, they are not updated on any regular basis. Scholars and research programs are not listed and no contacts for key staff and scholars. The majority of think tanks do not have bi-lingual (Chinese and English) and just a hand full have multilingual websites which limits the access and the ability to have impact on regional or global policy issues and debates. So, if the aspiration is to create great think tanks in China and to have influence around the world, English and multilingual websites are essential.

The last two I think are fundamental and require attention to the reform and modernization of think tanks in China. There is a complete lack of access to data by scholars at think tanks which undermines the credibility of what is produced. Many scholars and think tanks in China regularly complain that ministries and other 
government agencies have little or no access to the critical data that they need for their research.

Finally, there is a severe lack of adherence to the universally practiced social science research methods and standards. There is no access to data or the research methods which limits the ability to replicate studies that are produced and raise questions about the quality of the research. All of these basic, universal, and internationally accepted standards are not practiced or adhered to in China and that needs to change if Chinese think tanks are to "rival the great think tanks in the West." They must modernize and become smarter, better, and faster, if they have any hope of having national, regional, and global impact.

Those standards signify that accessing to data and the ability to replicate studies that are produced. All of these basic, universal, and internationally accepted standards are not practiced or adhered to in China. That needs to change if Chinese think tanks are to be smarter, better, faster, and to have both national, regional, and global impact.

China should join other think tanks around the world by adopting a set of basic standards for public policy research like ones that are now being considered by think tanks in every region of the world.

For centuries scholars, scientists, and think tanks around the world have embraced the scientific method and what have become known as social science research methods. These standards include a set of core elements that guide the quality and integrity of research around the world. The basic standards include the following: 1. the research should be based on empirical evidence and have a rationale for conducting it. More specifically, evidence should be provided to justify the key findings, results, and conclusions; 2 . the empirical research should be transparent, that is, reporting and the data sources should make explicit the logic of inquiry, the funding supporting it, and activities that led to initial interest in the issue, topic, problem, or research question, through the definition, collection, and analysis of data or empirical evidence to the articulated and support the outcomes of the study. Disclosing and reporting of the research methods takes these principles into account and enables other scholars, practitioners, and the public to understand the research, prepares that work for public scrutiny, and enables others to use the research for further research and for practical applications in policy. These standards are therefore intended to promote empirical research findings that are warranted and transparent. The reporting standards are divided into eight general areas: problem formulation; design and logic of the study; sources of evidence and data; measurement and classification; analysis and interpretation; generalization; ethics in reporting; and title, abstract, and headings.

\section{Advice for Think Tanks and Policy-Makers}

Covid-19 will influence all think tanks on several key points in a broader context. As I alluded to earlier, the disruptive and transformative dimensions of this crisis will have and will continue to alter all aspects of our lives and livelihood. We will not return to a new normal or any normal after this crisis. It is so transformative. The crisis has become the great accelerator, transformer, and terminator. What I mean by 
that is changes are accelerated and institutions are transformed. Many institutions will cease to exist as a result of this pandemic. 25 to $30 \%$ of certain organizations, private enterprises, and think tanks will close and not reopen.

Additionally, governments will have to take on huge and decimated budgets while also facing rising social, political, and economical challenges. Those institutions that have taken steps and this is important and a key message for think tanks in China. Those institutions that have taken steps to modernize their operations and implement digital and other strategies are more likely to survive the crisis. Key sectors such as higher education, medicine, travel and leisure, and information-based organizations will be most adversely affected.

This crisis and the economic impact it has are different from previous economic downturns because in the past the negative economic impact of a downturn such as the oil crisis plus the 2008 economic crisis hit both the rich and the middle class at about the same level. The COVID-19 crisis has widened the gap and created a huge gulf between rich and poor. That trend is likely to have long-term and destabilizing effects in countries around the world. Like all great wars, this crisis will create a global power shift, and China at the moment seems to be the only country, ironically, that is emerging from this crisis in a commanding economic position. That seems certain to have a highly transforming global and geopolitical impact.

Finally and most importantly, this is a massive wake-up call for all organizations to accelerate modernization and reform. Failure to respond and understand the forces that have been released means the very survival of many organizations is at stake. Every organization must embed into its goals to be smarter, better, faster, more agile, and more digital. If we come together as a community of think tanks and innovate and cooperate, we will beat this invisible beast and be better for it.

\section{References}

McGann JG (2004) Scholars, dollars and policy advice. Think Tanks and Civil Societies Program, pp 6-15

McGann JG (2007) Think tanks and policy advice in the US. Routledge, London. https://doi.org/ $10.4324 / 9780203963203$

McGann JG (2012) Chinese think tanks, policy advice and global governance. Indiana University Research Center for China Politics and Business. http://www.dragon-report.com/Dragon_Rep ort/home/home_files/mcgann-rccpb-21-think-tanks-march-2012.pdf

McGann JG (2014) China's first think tank summit was hosted in Shanghai by the Think Tanks and Civil Societies Program and the Shanghai Academy for Social Sciences. https://www.thedp. com/article/2014/07/chinese-think-tank-conference

McGann JG (2015a) Going global: what Chinese think tanks need to do to have global reach and impact. Think Tanks and Civil Societies Program, University of Pennsylvania

McGann JG (2015b) Expert advises China to build innovative think tanks. https://www.linkedin. com/pulse/expert-advises-china-build-innovative-think-tanks-james-mcgann/?articleId=779570 7204265141347

McGann JG (2016a) The fifth estate: think tanks, public policy, and governance. Brookings Institution Press, September

McGann JG (2016b) 2016 China global think tank innovation forum. https://repository.upenn.edu/ ttcsp_china_reports/4/ 
McGann JG (2016c) Think tanks in action: foreign policy case studies. In: The fifth estate: think tanks, public policy, and governance. Brookings Institution Press, Washington, DC, pp 114-148. http://www.jstor.org/stable/10.7864/j.ctt1gpccjc.8. Accessed 16 Oct 2020

McGann JG (2017a) 2017 China global think tank innovation forum. https://repository.upenn.edu/ ttcsp_china_reports/3/

McGann JG (2017b) 2016 global go-to think tanks report. University of Pennsylvania

McGann JG (2018a) 2018 China global think tank innovation forum. https://repository.upenn.edu/ ttcsp_china_reports/2/

McGann JG (2018b) Thinking aloud. Beijing Review. https://www.bjinforma.com/Current_Issue/ 2018/202102/t20210204_800235116.html

McGann JG (2019a) 2018 global go-to think tanks report. University of Pennsylvania

McGann JG (2019b) 2019 China global think tank innovation forum. China.org.cn. https://reposi tory.upenn.edu/cgi/viewcontent.cgi?article=1000\&context=ttcsp_china_reports

McGann JG (2019c) Promoting development of China's think tanks through global vision. http:// www.china.org.cn/china/2019-05/31/content_74841640.htm

McGann JG (2019d) Think tanks: the new policy advisors in Asia. Brookings Institution Press, Washington, DC

McGann JG (2020a) Let 1000 think tanks bloom in China. Speech presented at Think Tank Leader Knowledge Exchange Program in Beijing, China

McGann JG (2020b) 2019 global go to think tank index report. TTCSP global go to think tank index reports. https://repository.upenn.edu/cgi/viewcontent.cgi?article=1018\&context=think_tanks

McGann JG (2020c) Global think tank town hall report. University of Pennsylvania, April-July

McGann JG (2020d) Chinese think tank landscape workshop. University of Pennsylvania

McGann J, Whelan L (2020) Global think tanks: policy networks and governance. Routledge, London. https://doi.org/10.4324/9780429298318

McGann JG (2021) The future of think tanks and policy advice around the world. Palgrave Macmillan

James G. McGann is Director, Think Tanks and Civil Societies Program, Wharton School and School of Arts and Sciences; Senior Fellow, Fels Institute of Government, University of Pennsylvania. He has served as a Consultant and Advisor to the World Bank, the United Nations, and the Asian Development Bank to name just a few. He earned his M.A. and Ph.D. from the University of Pennsylvania. He has authored over 17 books on think tanks and is the Creator and Editor of the annual Global Go To Think Tank Index. He has traveled on assignments and programs to 114 countries.

Open Access This chapter is licensed under the terms of the Creative Commons AttributionNonCommercial-NoDerivatives 4.0 International License (http://creativecommons.org/licenses/bync-nd/4.0/), which permits any noncommercial use, sharing, distribution and reproduction in any medium or format, as long as you give appropriate credit to the original author(s) and the source, provide a link to the Creative Commons license and indicate if you modified the licensed material. You do not have permission under this license to share adapted material derived from this chapter or parts of it.

The images or other third party material in this chapter are included in the chapter's Creative Commons license, unless indicated otherwise in a credit line to the material. If material is not included in the chapter's Creative Commons license and your intended use is not permitted by statutory regulation or exceeds the permitted use, you will need to obtain permission directly from the copyright holder.

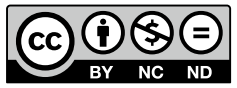

